\title{
Composition, functional properties and sensory characteristics of Mozzarella cheese manufactured from different somatic cell counts in milk
}

\author{
Evelise Andreatta ${ }^{1}$, Andrezza Maria Fernandes $^{1}$, Marcos Veiga Santos ${ }^{2}$, Camila \\ Mussarelli $^{1}$, Marina Célia Marques ${ }^{1}$ and Carlos Augusto Fernandes de Oliveira ${ }^{1 *}$ \\ ${ }^{I}$ Departamento de Engenharia de Alimentos; Faculdade de Zootecnia e Engenharia de Alimentos; Universidade de \\ São Paulo; Pirassununga - SP - Brasil. ${ }^{2}$ Departamento de Nutrição e Produção Animal; Faculdade de Medicina \\ Veterinária e Zootecnia; Universidade de São Paulo; Av. Duque de Caxias Norte, 225; 13635-900; Pirassununga - \\ SP - Brasil
}

\begin{abstract}
In the present study, composition, functional properties and sensory characteristics of Mozzarella cheese produced from milk with somatic cell counts $(S C C)$ at low $(<200,000$ cells $/ \mathrm{mL})$, intermediate $(\approx 400,000$ cells $/ \mathrm{mL})$ and high (>800,000 cells $/ \mathrm{mL}$ ) levels were investigated. Three batches of cheese were produced for each SCC category. The cheeses were vacuum packed in plastic bags and analysed after 2, 9, 16, 23 and 30 days of storage at $4^{\circ} C$. SCC level did not affect the moisture, fat, total protein and ash content, mesophilic and psychrotrophic bacteria, and sensory parameters of Mozzarella cheese. However, meltability increased in cheese manufactured from high SCC milk. Results indicated that raw milk used to produce Mozzarella cheese should not contain high SCC (>800,000 cells $/ \mathrm{mL}$ ) in order to avoid changes in the functional properties of the Mozzarella cheese.
\end{abstract}

Key words: somatic cell count, Mozzarella cheese, quality evaluation, functionality

\section{INTRODUCTION}

The inflammation of the mammary gland, or mastitis, is one of the most important factors that can negatively affect the raw milk quality (International Dairy Federation, 1987). Milk from infected cows is characterized by increased somatic cell counts (SCC) (Auldist and Hubble, 1998). The impact of mastitis to the dairy production is related to changes in milk composition, such as reduced calcium, lactose and casein levels, and increases in sodium, chloride, and levels of serum proteins. However, one of the most important adverse effect of high SCC milk on the dairy industry include reduced shelf life of dairy products, due to undesirable sensory attributes (Kitchen, 1981).

The SCC in milk markedly influences the overall quality of cheeses. Main alterations include: decreased cheese yield, increased fat and protein loss in whey (Barbano et al., 1991) and inferior organoleptic properties (Lee et al., 1991; Auldist et al., 1996). SCC effects on cheese manufacture have been well established for Cheddar

* Author for correspondence: carlosaf@usp.br 
(Grandison and Ford, 1986; Mitchell et al., 1986; Rogers and Mitchell, 1994; Politis and Ng-KwaiHang, 1988) and Cottage (Klei et al., 1998) varieties. However, very little information is available on the effects of mastitis and high SCC milk on the quality of other varieties, such as Mozzarella cheese.

Mozzarella cheese is commonly used as ingredient for pizza, and contributes to the organoleptic characteristics of the final product (Kindstedt, 1993). The ability of cheese to fulfill its expected requirements as an ingredient is related to its functional properties (Fox et al., 2000). Functionality parameters of Mozzarella cheese include meltability and free oil formation. Melting characteristics of the cheese are the prime factors in determining the appropriate pizza baking (Kuo et al., 2000). The excessive oiling off, or the tendency to form excessive free oil upon melting, is a defect that detracts from melted cheese appearance on pizza and related foods (Kindstedt and Rippe, 1990). There is no previous report on the effects of somatic cell counts on meltability and free oil formation of Mozzarella cheese.

In Brazil, Mozzarella cheese accounts for nearly $35 \%$ of the $375,000 \mathrm{~kg}$ of the total cheese produced in the country. The potential impact of high SCC in milk on the Mozzarella industry is not well understood. Therefore, the aim of the present study was to verify the effects of using different bulk milk SCC on the composition, microbiology, functionality and sensory characteristics of the Mozzarella cheese.

\section{MATERIALS AND METHODS}

\section{Milk collection}

Milk used in the present study was collected from two dairy herds located in Pirassununga, Brazil. Holstein cows were selected among the animals that were in intermediate stages of lactation, and that were not submitted to antibiotics treatment seven days before milk collection to avoid the residues in milks (Brito and Junqueira, 2006). Milk from individual cows was submitted to SCC using an electronic counter (Bentley, USA), to allow its distribution in three groups based on individual SCC status: cows with low SCC $(<200,000$ cells $/ \mathrm{mL})$, intermediate SCC $(\approx 400,000$ cells $/ \mathrm{mL})$ and high SCC $(>800,000$ cells $/ \mathrm{mL})$. Groups of cows of each SCC category were milked separately, two days after SCC measurement, to obtain milk for cheese processing. Milk collected from cows of the same group was bulked until a minimum amount of 100 $\mathrm{kg}$ was reached. Milk was then cooled and stored in a refrigerator $\left(4^{\circ} \mathrm{C}\right)$ until utilisation $(24 \mathrm{~h}$ after collection). Duplicate samples of bulked raw milk of each SCC category were analysed for composition (Association of Official Analytical Chemists, 1995) and confirmation of SCC in the electronic counter (Bentley, USA).

\section{Manufacture of Mozzarella cheese}

The manufacture of cheese was accomplished in two days, strictly following the procedures as described by Oliveira (1986). On day one, the raw milk $(100 \mathrm{~kg} / \mathrm{SCC}$ level $)$ was heat treated at $65^{\circ} \mathrm{C}$ for $30 \mathrm{~min}$, and then cooled to nearly $34^{\circ} \mathrm{C}$. All the procedures for the manufacture of cheese were performed in a double-jacketed stainless steel vat (Mec Milk, Brazil). Mesophilic and psychrotrophic bacteria were analysed on pasteurised milk (American Public Health Association, 1992) for confirmation of milk bacterial counts. Pasteurised $\left(65^{\circ} \mathrm{C}\right.$ for $\left.30 \mathrm{~min}\right)$ milk samples containing less than $1.0 \times 10^{2}$ colony forming units per $\mathrm{mL}$ of mesophilic or psychrotrophic bacteria were inoculated (3\% inoculum) with thermophilic starter culture (TCC20, Christian-Hansen, Brazil) and calcium chloride solution $(250 \mathrm{mg} / \mathrm{L})$, mixed and incubated at $34^{\circ} \mathrm{C}$, for approximately $60 \mathrm{~min}$. Forty milliliters of liquid rennet containing chymosin and pepsin (HaLa, Christian-Hansen, Brazil) was added to the milk, followed by mixing thoroughly for one minute and incubating at $34^{\circ} \mathrm{C}$ for $35 \mathrm{~min}$. After that, the coagulum was cut into small cubes of approximately $1.0 \mathrm{~cm}$ and gently stirred for 10 minutes, followed by cooking at $43^{\circ} \mathrm{C}$ for 25 minutes. At the end of cooking, the whey was drained and collected for the analysis. All fines in the whey were added back into the vat. The curd was then removed from the vat, placed in a polypropylene tray and covered with a plastic film. The trays were stored in a refrigerator at $4^{\circ} \mathrm{C}$ for 12-16 h, until pH 5.1-5.3 (Fox et al. 2000).

On day two, the cheese curd was cut into slices of nearly $0.5 \mathrm{~cm}$ thickness and placed in a vat containing water at $80-85^{\circ} \mathrm{C}$. The curd was stretched and kneaded for $5 \mathrm{~min}$, when it reached the typical elastic consistency of the Mozzarella cheese. The hot, plastic curd was then manually molded into rectangular blocks of $4 \mathrm{~kg}$, cooled in 
sterile cold water to $10^{\circ} \mathrm{C}$, and brine salted $\left(20^{\circ} \mathrm{B}\right)$ for $20 \mathrm{~h}$. After salting, the cheese was dried for 48 $\mathrm{h}$ in a refrigerator at $4^{\circ} \mathrm{C}$, vacuum packed in polyethylene bags, and stored for 30 days. The experiment was replicated three times, once per month, representing nine batches of cheeses, three within each SCC category. Analyses of Mozzarella cheeses were performed in duplicate samples after $2,9,16,23$ and 30 days of storage at $4^{\circ} \mathrm{C}$.

\section{Composition and microbiological analysis}

Cheese moisture, fat, total protein and ash were determined on day 2 of storage according to the Association of Official Analytical Chemists (1995) methods. Microbiological tests included standard plate count for mesophilic and psychrotrophic bacteria (American Public Health Association, 1992).

\section{Functional properties}

Functional properties of Mozzarella cheese were evaluated by means of free oil and meltability determinations. Free oil was measured using a modified Gerber method, as described by Kindstedt and Fox (1991). A modified Schreiber test (Kosikowski, 1982) was used to quantify cheese meltability.

\section{Sensory analyses}

Samples of Mozzarella cheese were submitted to a non-trained panel of 50 individuals (Institute of
Food Technologists, 1981) recruited among the students and staff of the University of São Paulo. Samples were cut into portions of approximately 30 grams and submitted to the panel without addition of any other ingredients, at approximately $10^{\circ} \mathrm{C}$. Panelists were unable to identify the samples and were instructed to follow a hedonic scale of 9 points and attribute scores to each of the following cheese characteristics: appearance, consistency, odour and taste. The descriptions used for the hedonic scale were: 9=excellent, $8=$ very good, 7=good, 6=fairly good, 5=indifferent, 4=fairly poor, $3=$ poor, $2=$ very poor, $1=$ extremely poor.

\section{Statistical analyses}

Results on milk and cheese composition of the nine batches were submitted to one-way ANOVA (Gacula and Singh, 1984) and treatment means were compared by the Tukey test, using the SAS ${ }^{\circledR}$ General Linear Model (SAS Institute, 2004). A split-plot design was used to monitor the effects of treatment, storage time, and the interaction of the functional properties and sensory grades of cheeses at intervals during the 30 days of storage. Analysis of variance for the split-plot design was carried out using the PROCMIXED of SAS ${ }^{\circledR}$ software (SAS Institute, 2004). Statistical significance was accepted at $\mathrm{P}<0.05$. The ANOVA models used for the statistical analysis of functional and sensory characteristics are listed in Table 1.

Table 1 - The ANOVA models used for the analysis of functional and sensory characteristics.

\begin{tabular}{lclc}
\hline Model terms & df & Analysed as & Error term \\
\hline SCC & 2 & Whole plot factor (fixed) & E (a) \\
E (a) & 12 & Whole plot error & \\
T & 4 & Subplot (fixed) & E (b) \\
SCC x T & 8 & Interaction (fixed) & E (b) \\
E (b) & 96 & Subplot error & \\
Model equation & \multicolumn{4}{r}{ Y SCC + E (a) + T + SCC x T + E (b) } \\
SCC = somatic cell counts, E = error, and T = time of storage.
\end{tabular}

\section{RESULTS AND DISCUSSION}

The results of composition analyses of raw milk used for the Mozzarella cheeses production in each SCC category are presented in Table 2. Average SCC in low, intermediate and high SCC milk samples differed statistically $(\mathrm{P}<0.05)$, with average of $5.15 \log$ cells $/ \mathrm{mL}, 5.67 \log$ cells $/ \mathrm{mL}$ and $6.02 \mathrm{log}$ cells $/ \mathrm{mL}$, respectively. No significant differences were detected between the evaluated characteristics for the different milks studied $(\mathrm{P}>0.05)$, except for the fat and total protein content, which were higher $(\mathrm{P}<0.05)$ in high SCC milk. A higher fat and total protein content of milk with high SCC has been described previously by Marques et al. (2002) and Auldist et al. (1995), respectively.

The composition and microbiological parameters of Mozzarella cheese produced from milk of each SCC category are shown in Table 3. No effect 
$(\mathrm{P}>0.05)$ of milk SCC was observed on the moisture, fat, total protein and ash, as well as mesophile counts. Psychrotrophic bacteria were not detected in the cheeses on day 2 of storage.

Table 2 - Composition of cow milk used for the manufacture of Mozzarella cheese within selected somatic cell count categories ${ }^{1}$.

\begin{tabular}{|c|c|c|c|c|}
\hline \multirow[t]{2}{*}{ Parameter } & \multicolumn{3}{|c|}{ SCC Category (cells/mL) } & \multirow[b]{2}{*}{ MSD $^{2}$} \\
\hline & $<200,000$ & $\approx 400,000$ & $>800,000$ & \\
\hline Somatic cell count (log cells/mL) & $5.15 \pm 0.06^{\mathrm{c}}$ & $5.67 \pm 0.01^{\mathrm{b}}$ & $6.02 \pm 0.06^{\mathrm{a}}$ & 0.16 \\
\hline Titratable acidity $\left({ }^{\circ} \mathrm{D}\right)$ & $17.67 \pm 2.89^{\mathrm{a}}$ & $17.83 \pm 1.61^{\mathrm{a}}$ & $16.50 \pm 0.87^{\mathrm{a}}$ & 4.16 \\
\hline Total solids $(\%)$ & $11.60 \pm 1.18^{\mathrm{a}}$ & $11.59 \pm 1.23^{\mathrm{a}}$ & $12.33 \pm 0.78^{\mathrm{a}}$ & 0.81 \\
\hline Fat $(\%)$ & $3.10 \pm 0.89^{\mathrm{b}}$ & $3.14 \pm 0.83^{\mathrm{b}}$ & $3.86 \pm 0.55^{\mathrm{a}}$ & 0.55 \\
\hline Total protein $(\%)$ & $3.00 \pm 0.24^{\mathrm{b}}$ & $3.14 \pm 0.25^{\mathrm{ab}}$ & $3.27 \pm 0.26^{\mathrm{a}}$ & 0.23 \\
\hline Lactose $(\%)$ & $4.52 \pm 0.07^{\mathrm{a}}$ & $4.42 \pm 0.18^{\mathrm{a}}$ & $4.33 \pm 0.12^{\mathrm{a}}$ & 0.31 \\
\hline
\end{tabular}

Within a row, means followed by the same letter are not significantly different $(\mathrm{P}>0.05)$.

${ }^{1}$ Mean + standard deviation of duplicate analyses of three lots of each SCC category.

${ }^{2} \mathrm{MSD}=$ Tukey's minimum significant difference at $\alpha=0.05$.

Table 3 - Composition and microbiological characteristics of Mozzarella cheese manufactured from milk within selected somatic cell count categories ${ }^{1}$.

\begin{tabular}{|c|c|c|c|c|}
\hline \multirow[t]{2}{*}{ Parameter } & \multicolumn{3}{|c|}{ SCC Category (cells/mL) } & \multirow[b]{2}{*}{ MSD $^{2}$} \\
\hline & $<200,000$ & $\approx 400,000$ & $>800,000$ & \\
\hline Moisture (\%) & $49.21 \pm 1.46^{\mathrm{a}}$ & $49.71 \pm 0.70^{\mathrm{a}}$ & $49.07 \pm 3.06^{\mathrm{a}}$ & 5.51 \\
\hline Fat $(\%)$ & $26.17 \pm 4.07^{\mathrm{a}}$ & $26.17 \pm 2.47^{\mathrm{a}}$ & $26.83 \pm 2.75^{\mathrm{a}}$ & 6.13 \\
\hline Total protein $(\%)$ & $22.32 \pm 3.14^{\mathrm{a}}$ & $20.92 \pm 2.79^{\mathrm{a}}$ & $19.38 \pm 1.05^{\mathrm{a}}$ & 5.34 \\
\hline Ash $(\%)$ & $4.51 \pm 1.88^{\mathrm{a}}$ & $4.55 \pm 2.10^{\mathrm{a}}$ & $3.86 \pm 1.33^{\mathrm{a}}$ & 1.42 \\
\hline Mesophiles (log CFU/g) & $6.76 \pm 0.34^{\mathrm{a}}$ & $6.76 \pm 0.08^{\mathrm{a}}$ & $6.55 \pm 0.11^{\mathrm{a}}$ & 0.44 \\
\hline
\end{tabular}

Within a row, means followed by the same letter are not significantly different $(\mathrm{P}>0.05)$.

${ }^{1}$ Mean \pm standard deviation of duplicate analyses of three lots of each SCC category analysed on day 2 of storage.

${ }^{2} \mathrm{MSD}=$ Tukey's minimum significant difference at $\alpha=0.05$.

Table 4 presents the free oil values of Mozzarella cheeses during 30 days of storage. SCC did not affect the free oil formation $(\mathrm{P}>0.05)$ and no interaction was found between SCC and the days of storage $(\mathrm{P}>0.05)$. However, a significant increase in free oil release was observed during the storage $(\mathrm{P}<0.05)$.

Table 4 - Effect of somatic cell counts (SCC) on free oil release, as a percentage of Mozzarella cheese fat, during storage at $4^{\circ} \mathrm{C}^{1}$.

\begin{tabular}{|c|c|c|c|c|c|}
\hline \multirow[b]{2}{*}{ SCC } & \multicolumn{5}{|c|}{ Time of storage (days) } \\
\hline & 2 & 9 & 16 & 23 & 30 \\
\hline (cells/mL) & \multicolumn{5}{|c|}{ 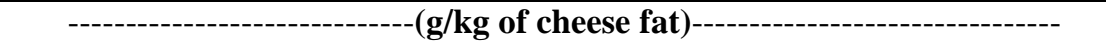 } \\
\hline$<200,000$ & 20.62 & 19.78 & 24.21 & 25.42 & 20.98 \\
\hline$\approx 400,000$ & 23.27 & 21.20 & 23.29 & 27.46 & 25.04 \\
\hline$>800,000$ & 26.70 & 22.99 & 29.78 & 30.42 & 27.75 \\
\hline Standard error & 2.87 & 2.09 & 2.99 & ‘ 1.69 & 2.64 \\
\hline Source of variation & \multicolumn{5}{|c|}{------------------------------------------------ $\mathbf{P}$------------------------------------------------ } \\
\hline SCC & \multicolumn{5}{|c|}{0.1268} \\
\hline Time & \multicolumn{5}{|c|}{$0.0029 *$} \\
\hline SCC $\mathrm{x}$ time & \multicolumn{5}{|c|}{0.9806} \\
\hline
\end{tabular}

${ }^{1}$ Means of duplicate analyses of three lots of each SCC category.

* Linear effect: $y=0.8555 x+22.07\left(R^{2}=0.32\right)$. 
The amount of free oil released from Mozzarella depended on the proteolysis level during the storage, and the excess of free oil on the surface of a pizza after baking was a major quality defect for Mozzarella cheese manufacturers (Kindstedt and Rippe, 1990). Oiling off occurs when the casein matrix collapses during the heating, allowing the fat globules to coalesce and to flow to the surface. In the present study, SCC had a significant effect $(\mathrm{P}<0.05)$ on the meltability of cheeses (Table 5). The increase in the melted diameter of cheeses is related to the proteolysis in cheese during storage (Tunick et al., 1993). Therefore, as the matrix was degraded by the proteolysis, the ability of the cheese to maintain its structure during heating decreased. There has been no previous evidence that the differences in milk composition, as observed in the present experiment for protein and fat content in the high SCC milk, may play a significant role in the meltability of Mozzarella cheese. The high meltability observed in high SCC cheeses could lead to a higher fluidity of melted cheese, which might cause alterations in spread characteristics of cheese, leading to a lower acceptance from the consumers (Pizaia et al., 2003). The melted diameter of cheeses increased up to 30 days of storage $(\mathrm{P}<0.05)$, and there was a significant interaction between SCC and time of storage $(\mathrm{P}<0.05)$. In fact, age has a large impact on the meltability of cheeses (Kindsted, 1993). Soon after the manufacture of the cheese, proteins have a high molecular weight and consequently lower solubility. After two or three weeks, proteins are hydrolysed and meltability is increased until become excessive and inappropriate (Oliveira, 1986; Kindsted, 1993). Although the casein and the proteolysis index of Mozzarella cheeses was not evaluated in the present study, the higher meltability of high SCC cheeses could be a consequence of higher protein degradation, since previous reports indicated that proteolysis was increased in Cheddar cheese manufactured from milk with 500,000 cells/mL (Rogers and Mitchell, 1994), in Cottage cheese made with milk at 872,000 cells $/ \mathrm{mL}$ (Klei et al., 1998), and in Prato cheese made from milk with $>600,000$ cells $/ \mathrm{mL}$ (Mazal et al., 2007).

Table 5 - Effect of somatic cell counts (SCC) on the melted diameter (mm) of Mozzarella cheese during storage at $4^{\circ} \mathrm{C}^{1}$.

\begin{tabular}{|c|c|c|c|c|c|}
\hline \multirow[b]{2}{*}{ SCC } & \multicolumn{5}{|c|}{ Time of storage (days) } \\
\hline & 2 & 9 & 16 & 23 & 30 \\
\hline (cells/mL) & \multicolumn{5}{|c|}{-----------------------------------------(mm)----------------------------------------- } \\
\hline$<200,000$ & 3.81 & 3.63 & 3.56 & 3.99 & 4.14 \\
\hline$\approx 400,000$ & 3.65 & 3.98 & 3.81 & 4.63 & 4.48 \\
\hline$>800,000$ & 3.68 & 4.41 & 4.35 & 5.03 & 4.72 \\
\hline Standard Error & 0.03 & 0.10 & 0.09 & 3.99 & 4.14 \\
\hline Source of variation & \multicolumn{5}{|c|}{ 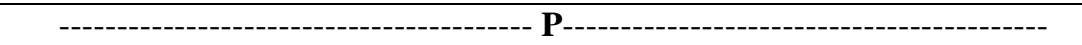 } \\
\hline SCC & \multicolumn{5}{|c|}{$0.0046^{*}$} \\
\hline Time & \multicolumn{5}{|c|}{$<0.0001 * *$} \\
\hline SCC $x$ time & \multicolumn{5}{|c|}{$<0.0001 * * *$} \\
\hline \multicolumn{6}{|c|}{$\begin{array}{l}{ }^{1} \text { Mean of duplicate analyses of three lots of each SCC category. } \\
* \text { Linear effect: } \mathrm{y}=0.3077 \mathrm{x}+3.5095\left(\mathrm{R}^{2}=0.99\right) \\
{ }^{* *} \text { Linear effect: } \mathrm{y}=0.1991 \mathrm{x}+3.5267\left(\mathrm{R}^{2}=0.78\right) \\
* * * \text { Linear effect: }<200,000: \mathrm{y}=0.10 \mathrm{x}+3.524\left(\mathrm{R}^{2}=0.44\right) ; \approx 400,000: \mathrm{y}=0.231 \mathrm{x}+3.417\left(\mathrm{R}^{2}=0.74\right) ;>800,000: \mathrm{y}=0.27 \mathrm{x} \\
3.628\left(\mathrm{R}^{2}=0.72\right)\end{array}$} \\
\hline
\end{tabular}

Figure 1 presents the mean grades of sensorial characteristics of Mozzarella cheeses for the three SCC studied. SCC in milk influenced the appearance and consistency of cheeses $(\mathrm{P}<0.001$ and $\mathrm{P}=0.0107$, respectively). Compared with the low and high SCC categories, cheeses made with intermediate SCC milk had higher grades for the attribute appearance $(\mathrm{P}<0.05)$. The mean grade of intermediate SCC cheeses for consistency was higher $(\mathrm{P}<0.05)$ than the high SCC group. However, no differences $(\mathrm{P}>0.05)$ were found between the grades of all sensory attributes in low and high SCC cheeses. Lee et al. (1991) and Auldist et al. (1996) reported lower sensory characteristics of Cheddar cheese made from SCC milks at levels above 1,500,000 cells $/ \mathrm{mL}$, which was much higher than the levels used in the present experiment. Also, a possible explanation 
for the difference between those reports and data obtained in the present study could be the different ripening patterns among cheese varieties. Mozzarella is a short-ripened cheese that is released for consumption 2-3 days after manufacture, while Cheddar cheese is usually matured at $6-10^{\circ} \mathrm{C}$ for a period ranging from 3-4 months to two years (Fox et al., 2000). This long period would allow the prolonged action of proteolytic enzymes present in high SCC milk, leading to a greater sensory modification in Cheddar when compared to the Mozzarella cheese. The grades for all the sensorial characteristics evaluated significantly increased during 30 days of storage (Fig. 2). The $\mathrm{P}$ values were 0.0038, $0.0004,<0.0001$ and $<0.0001$ for appearance, odour, consistency and taste, respectively. The reason for the increase in odour and taste grades might be due to the action of starter culture during the storage.

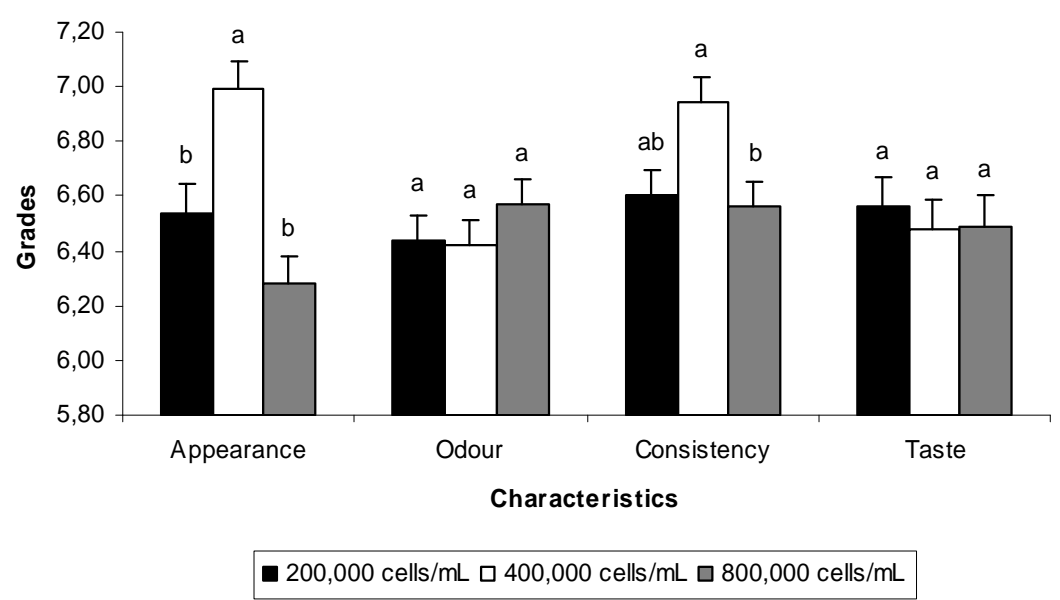

Figure 1 - Effect of SCC on sensory attributes of Mozzarella cheese during 30 days of storage. Results are mean grades with bars of standard error of individual scores obtained from 50 panellists. Within each sensory attribute, means followed by the same letter are not significantly different $(\mathrm{P}>0.05)$.

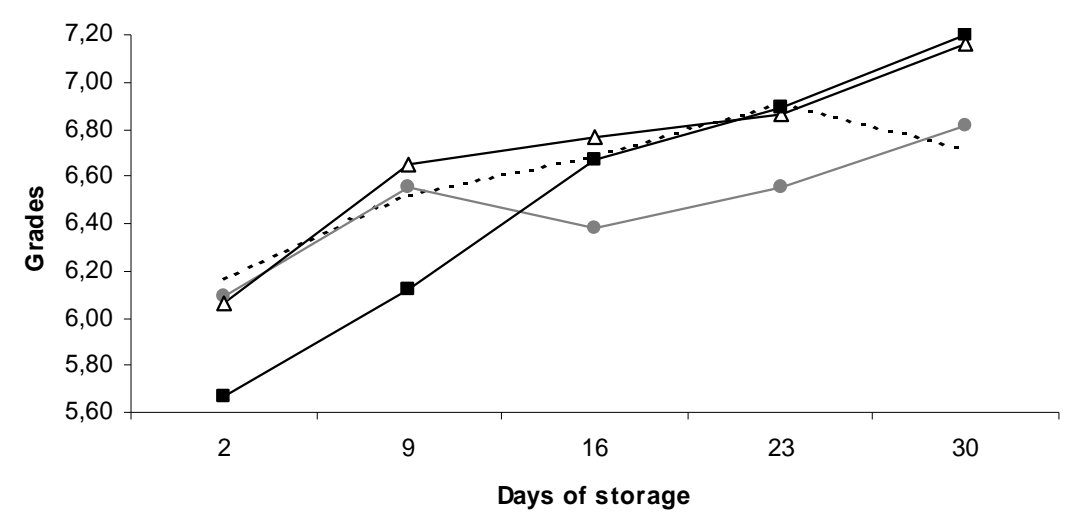

...... Appearance $\longrightarrow$ Odour $\longrightarrow-$ Consistency $\longrightarrow-$ Taste

Figure 2 - Sensory characteristics of Mozzarella cheese on days 2, 9, 16, 23 and 30 of storage. Results are mean grades of individual scores obtained from 50 panellists. 
The interaction between SCC and day of storage was observed only for the appearance of cheeses $(\mathrm{P}<0.0001)$. The linear regression lines predicting the grades according to the interaction between SCC and time were $5.756+0.262 \mathrm{X}\left(\mathrm{R}^{2}=0.44\right)$ for cheese made from milk with low SCC, $5.795+$ $0.397 \mathrm{X}\left(\mathrm{R}^{2}=0.91\right)$ for intermediate SCC cheese, and $6.928-0.216 \mathrm{X}\left(\mathrm{R}^{2}=0.28\right)$ for the cheeses from the high SCC category, where $\mathrm{X}$ is the days of storage.

\section{CONCLUSIONS}

Results of this study indicated that SCC in milk was not a major factor that could negatively affect the composition and sensory characteristics of Mozzarella cheese over 30 days of storage. However, increased SCC in milk led to higher meltability that could result in lower quality of Mozzarella cheese intended for use as ingredient, especially for pizza. Based on these results it could be suggested that cow milk used to produce Mozzarella cheese should not contain SCC over 800,000 cells $/ \mathrm{mL}$ in order to avoid inferior functional properties of the Mozzarella cheese.

\section{ACKNOWLEDGEMENTS}

The authors thank the Fundação de Amparo à Pesquisa do Estado de São Paulo (FAPESP, Brazil; grants no. 2003/01791-0 and 2003/017926 ) for the financial support.

\section{RESUMO}

No presente estudo foram investigadas a composição, as propriedades funcionais $\mathrm{e}$ as características sensoriais do queijo Mussarela produzido a partir de leite com contagens de células somáticas (CCS) em níveis baixos $(<200.000 \quad \mathrm{CS} / \mathrm{mL})$, intermediários $\quad(\approx 400.000$ $\mathrm{CS} / \mathrm{mL})$ e altos (>800.000 CS/mL). Foram produzidos 3 lotes de queijo para cada CCS. Os queijos foram embalados a vácuo e analisados após $2,9,16,23$ e 30 dias de armazenamento a $4^{\circ} \mathrm{C}$. O nível de CS não afetou a umidade, os teores de gordura, proteína total e cinzas, os níveis de bactérias mesófilas e psicrotróficas, e os parâmetros sensoriais do queijo Mussarela.
Entretanto, houve aumento da capacidade de derretimento no queijo fabricado com leite de alta CCS. Os resultados indicam que o leite cru utilizado para a produção de queijo Mussarela não deve conter níveis de CS acima de 800.000/mL, para evitar alterações nas propriedades funcionais do queijo Mussarela.

\section{REFERENCES}

American Public Health Association (1992), Standard Methods for the Examination of Dairy Products. 16th Edition. Washington D C: APHA.

Association of Official Analytical Chemists (1995), Official Methods of Analysis. 16th Edition. Arlington VI: AOAC.

Auldist, M. J. and Hubble, I. B. (1998), Effects of mastitis on raw milk and dairy products. Austr. J. Dairy Technol., 53, 28-36.

Auldist, M. J.; Coats, S.; Rogers, G. L. and McDowell, G.H. (1995), Changes in the composition of milk from normal and mastitic dairy cows during the lactation cycle. Austr. J. Exp. Agric., 35, 427-436.

Auldist, M.J.; Coats, S.; Sutherland, B.J.; Mayes, J.J.; McDowell, G. H. and Rogers, G. L. (1996), Effects of somatic cell count and stage of lactation on raw milk composition and the yield and quality of cheddar cheese. J. Dairy Res., 63, 269-280.

Barbano, D. M.; Rasmussen, R. R. and Lynch, J. M. (1991), Influence of milk SCC and milk age on cheese yield. J.Dairy Sci., 74, 369-388.

Brito, R.B. and Junqueira, R.G.. (2006), Determination of beta-lactam residues in milk by high performance liquid chromatography. Brazilian Archives of Biology and Technology., 49, 41-46.

Fox, P. F.; Guinee, T. P.; Cogan, T. M. and McSweeney, P. L. H. (2000), Fundamentals of Cheese Science. Gaithersburg: Aspen Publishers. pp. 587.

Gacula, J. R. and Singh, J. (1984), Statistical Methods in Food and Consumer Research. Orlando: Academic Press. pp. 505.

Grandison, A. S. and Ford, G. D. (1986), Effects of variations in somatic cell count on the rennet coagulation properties of milk and on the yield, composition and quality of cheddar cheese. J.Dairy Res., 53, 645-655.

Institut of Food Technologists (1981), Sensory evaluation guide for testing food and beverage products. Food Technol., 35, 50-59.

International Dairy Federation (1987), Bovine mastitis - definition and guidelines for diagnosis. Bulletin Int. Dairy Fed., 211, 7.

Kindstedt, P. S. and Rippe, J. K. (1990), Rapid quantitative test for free oil (oiling off) in melted Mozzarella cheese. J. Dairy Sci., 73, 867-873. 
Kindstedt, P. S. (1993), Mozzarela and pizza cheese. In: Cheese: Chemistry, Physics and Microbiology. 1st Edition. (Ed PF Fox). London: Elsevier Applied Science. pp. 337-362.

Kindstedt, P. S. and Fox, P. F. (1991), Modified Gerber test for free oil melted Mozzarela Cheese. J. Food Sci., 56, 1115-1116.

Kosikowski, F. V. (1982) Cheese and fermented milk foods. 3th Edition. Ann Arbor, MI: Edwards Bros. pp. 406.

Kitchen, B. J. (1981), Reviews of the progress of dairy science: Milk compositional changes and related diagnostic tests. J. Dairy Res., 48, 167-188.

Klei, L.; Yun, J.; Sapru, A.; Lynch, J.; Barbano, D.; Sears, P. and Galton, D. (1998), Effects of milk somatic cell count on Cottage cheese yield and quality. J. Dairy Sci., 81, 1205-1213.

Kuo, M. I.; Wang, Y. C. and Gunasekaran, S. (2000), A viscoelasticity index for cheese meltability evaluation. J. Dairy Sci., 82, 412-417.

Lee, S. C.; Yu, J.H.; Jeong, C. L.; Back, Y. J. and Yoon, Y. C. (1991), The influence of mastitis on the quality of raw milk and cheese. Korean J. Dairy Sci., 13, 217-223.

Marques, L. T.; Balbinotti, M. and Fischer, V. (2002), Variations in the milk chemical composition according to somatic cell count. In: II Panamerican Congress on Milk Quality and Mastitis Control, Ribeirão Preto: IFC/Milkpoint.

Mazal, G.; Vianna, P. C. B.; Santos, M. V. S. and Gigante, M. L. (2007), Effect of somatic cell count on Prato cheese composition. J. Dairy Sci., 90, 630-636.

Mitchell, G.E.; Fedrick, I.A. and Rogers, S.A. (1986), The relationship between somatic cell count, composition and manufacturing properties of bulk milk. Cheddar cheese from farm bulk milk Austr. J. Dairy Technol., 41, 12-14.

Oliveira, J. S. (1986), Cheese: Technological fundaments. 2nd Edition. Campinas: Unicamp. pp. 146
Pizaia, P. D.; Spadoti, L. M.; Narimatsu, A.; Dornellas, J. R. F. and Roig, S. M. (2003), Composition, proteolysis, meltability and blisters formation of Mozzarella cheese obtained from traditional and ultrafiltration methods. Ciên. Tecnol. Alim., 23, 485491.

Politis, I. and Ng-Kwai-Hang, K. F. (1988), Effects of somatic cell counts and milk composition on cheese composition and cheese making efficiency. J. Dairy Sci., 71, 1711-1719.

Rogers, S. A. and Mitchell, G. E. (1994), The relationship between somatic cell count, composition and manufacturing properties of bulk milk. 6 . Cheddar cheese and skim milk yoghurt. Austr. J. Dairy Technol., 49, 70-74.

SAS Institute (2004), SAS ${ }^{\circledR}$ User's Guide: Statistics. Cary, NC: SAS Institute Inc.

Tunick, M. H.; Mackey, K. L.; Shieh, J. J.; Smith, P. W.; Cooke, P. and Malin, E. L. (1993), Rheology and microstructure of low-fat Mozzarella cheese. Int. Dairy J., 3, 649-662.
Received: March 27, 2007; Revised: July 24, 2007; Accepted: October 27, 2008. 